\title{
Potassium solubilization in phonolite rock by diazotrophic bacteria
}

\author{
Ligiane Aparecida Florentino*, Adauton Vilela Rezende, Cássia Cristina Bachião Miranda,
} Aline Carvalho Mesquita, José Ricardo Mantovani, Hudson Carvalho Bianchini

José do Rosário Vellano University, Alfenas, MG, Brazil

*Corresponding author, e-mail: ligianeflorentino@gmail.com

\begin{abstract}
Some strains of nitrogen fixing bacteria, besides fixing the $\mathrm{N}_{2}$, can produce phytohormones, control pathogens, act in solubilization of minerals containing phosphorus (P) and potassium (K), contributing to plant growth. However, the solubilization of minerals containing $K$ has been little exploited. Therefore, the aim of this study was to evaluate potassium solubilization (K) of phonolite rock by strains of associative nitrogen fixing bacteria supplied with two different carbon sources. Twelve bacterial strains were cultured for seven days at $25^{\circ} \mathrm{C}$ in Aleksandrov medium supplemented with phonolite rock powder. The experiment was carried out in a completely randomized factorial design, $13 \times 2$ (12 bacterial strains and a control without inoculation) and two carbon sources (glucose and sucrose) with four repetitions. After the growth, the supernatant was separated by centrifugation and analyzed for the final $\mathrm{pH}$ value and the content of $\mathrm{K}$. All diazotrophic bacteria strains contributed to increase the release of $\mathrm{K}$ when compared to the control treatment. The strain UNIFENAS 100-94 solubilized 130 $\mathrm{mg} \mathrm{L}^{-1} \mathrm{~K}$ in the presence of the two carbon sources, indicating the potential use of these diazotrophic bacterial strains for $\mathrm{K}$ solubilization from minerals.
\end{abstract}

Keywords: bio-solubilization, carbon source, rock powder

\section{Solubilização de potássio da rocha fonolito por bactérias diazotróficas}

\section{Resumo}

Algumas estirpes de bactérias diazotróficas, além de fixar $\circ \mathrm{N}_{2}$, são capazes de produzir fitormônios, controlar patógenos e solubilizar minerais que contenham fósforo $(P)$ e potássio $(K)$, contribuindo para o crescimento vegetal. No entanto, a solubilização de minerais contendo $K$ tem sido pouco explorada. Portanto, o objetivo deste estudo foi avaliar a solubilização de potássio (K) da rocha fonolito por estirpes de bactérias diazotróficas associativas supridas com duas fontes diferentes de carbono. Foram utilizadas 12 estirpes bacterianas cultivadas por sete dias a $25^{\circ} \mathrm{C}$ em meio líquido Aleksandrov suplementado com pó de rocha fonolito. O experimento foi instalado em delineamento inteiramente casualizado, em esquema fatorial $13 \times 2$ (12 estirpes bacterianas e um controle sem inoculação) e duas fontes de carbono (glicose e sacarose) com quatro repetições. Após o cultivo, o sobrenadante foi separado por centrifugação e analisado o valor do pH final e a concentração de K. A redução do pH foi diretamente relacionada à maior concentração de K. Todas as estirpes bacterianas diazotróficas contribuíram para maior liberação de K quando comparado ao tratamento controle, destacando-se a estirpe UNIFENAS 100-94, que solubilizou cerca de $130 \mathrm{mg} \mathrm{L}^{-1}$ de K na presença das duas fontes de carbono, indicando o potencial de utilização desta estirpe bacteriana diazotrófica e solubilizadora de minerais contendo K na agricultura.

Palavras chave: biosolubilização, fonte de carbono, pó de rocha 


\section{Introduction}

The biological nitrogen fixation process (BNF), performed by diazotrophic bacteria or $\mathrm{N}_{2}$ fixers can provide economic advantages and greater sustainability to agroecosystems (Moreira et al., 2010). In addition to N, bacteria can contribute to plant growth through several mechanisms, such as the production of phytonutrients and the increase in the release of nutrients in minerals of low solubility, being considered the bacteria that promote plant growth (Moreira et al., 2010; Phua et al., 2012).

In order to evaluate the solubility of minerals by diazotrophic bacteria, a large part of the studies are related to the solubilization of phosphorus-containing minerals (Souchie et al., 2005; Barroso \& Nahas, 2008; Lira-Cadete et al., 2012). However, it is necessary to evaluate the potential of bacteria in solubilizing other minerals that contain elements of economic importance, such as potassium (K), nutrient which Brazil import about $90 \%$ of the total amount used in agriculture (Anda, 2012). The high dependence of the foreign market is due to the lower national production, in which most part came from Silvinite and Carnalite, which contribute to less than $10 \%$ of the national demand (DNPM, 2014).

One of the rocks that has been studied as a potential source of $K$ is the volcanic phonolite found in Poços de Caldas, MG, Brazil, which presents $8.0 \%$ of total $\mathrm{K}_{2} \mathrm{O}$. The low concentration of soluble $\mathrm{K}_{2} \mathrm{O}$ present in the phonolite may be due to the predominance of some constituent minerals such as: microcline $\left(\mathrm{KAISi}_{3} \mathrm{O}_{8}\right)$, orthoclase $\left(\mathrm{KAISi}_{3} \mathrm{O}_{8}\right)$, andesine $\left[(\mathrm{Na}, \mathrm{Ca})(\mathrm{Si}, \mathrm{Al})_{4} \mathrm{O}_{8}\right]$ and $\mathrm{e}$ nepheline [( $\left.\mathrm{Na}, \mathrm{K}) \mathrm{AlSiO}_{4}\right]$ (Teixeira et al., 2012), where $K$ is retained by covalent bonds in the crystalline network of the mineral, presenting low $K$ release to the soil solution (Martins et al., 2008). Researches carried out with the rock powder presented satisfactory results when it was used in the same proportion of potassium chloride ( $\mathrm{KCl}$ ) (Mancuso, 2012; Padua, 2012).

Some microbial species are able to solubilize minerals, releasing $k$ to the solution and increasing the availability of this nutrient in the soil, consequently contributing to plant development Wu et al., 2005; Girgis et al., 2008; Basak \& Biswas, 2009; Leaungvutiviroj et al., 2010;
Parmar \& Sindhu, 2013; Meena et al., 2014). Alves et al. (2010) reported the efficiency of ectomycorrhizal fungi in providing $P$ and $K$ from rock powder for the development of eucalyptus. Considering the conditions of Brazilian soils, with high acidity and low natural fertility, researches associating $\mathrm{N}_{2}$ fixation and $\mathrm{K}$ solubilization are of great relevance, especially for extensive areas, where the lack of nutrient replacement, such as $\mathrm{N}$ and $\mathrm{K}$ have been identified as one of the causes of degradation (Bonfim-Silva \& Monteiro, 2006).

Therefore, the selection and identification of these microorganisms is of great importance, since it would make possible the use of rock powder, reducing the external dependence of fertilizers and providing greater sustainability to the ecosystems. However, different crop conditions such as rock type, carbon source, temperature and $\mathrm{pH}$ may interfere with the amount of $K$ released by the microorganisms (Parmar \& Sindhu, 2013), being important to consider these parameters in the initial studies involving selection of mineral containing $\mathrm{K}$ solubilizing microorganisms.

Thus, the objective of this study was to evaluate the potassium (K) solubilization of phonolite rock by strains of associative diazotrophic bacteria supplied with two different carbon sources.

\section{Material and Methods}

In the present study, 12 strains of diazotrophic bacteria belonging to the collection of the Microbiology Laboratory of Unifenas and isolated from rhizosphere soils cultivated with Urochloa brizantha cv. Marandu, in the municipalities of Alfenas and Machado, Minas Gerais, were used. These bacteria were isolated from four semi-selective semi-solid culture media (JMV, JNFb, LGI and NFb) for the genera Burkholderia-JMV (Baldani et al., 2000), Herbaspirillum-JNFb, Azospirillum amazonenseLGI and Azospirillum spp.- NFb (Döbereiner et al., 1995). On Table 1 is possible to observe the main characteristics of the bacterial strains used in this study.

The bacterial strains were cultured on potato liquid medium under agitation for three 
Table 01. Identification, isolation site, potassium concentration in soils of origin, medium used for bacteria isolation and morphological characteristics of strains cultured in potato agar dextrose (BDA) medium containing bromothymol blue as $\mathrm{pH}$ indicator.

\begin{tabular}{|c|c|c|c|c|c|}
\hline \multirow[t]{2}{*}{ Strains } & \multirow{2}{*}{ 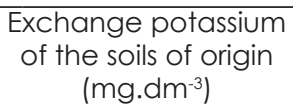 } & \multirow{2}{*}{$\begin{array}{l}\text { Culture } \\
\text { medium of } \\
\text { origin }\end{array}$} & \multicolumn{3}{|c|}{$\begin{array}{c}\text { Morphological characteristics in BDA culture } \\
\text { medium }\end{array}$} \\
\hline & & & $\mathrm{pH}$ & Color & EPS(1) \\
\hline \multicolumn{6}{|c|}{ Isolated in the municipality of Alfenas, MG } \\
\hline UNIFENAS 100-01 & 114 & JNFb & Acid & Yellow & Low \\
\hline UNIFENAS 100-16 & 30 & JMV & Acid & Yellow & Low \\
\hline UNIFENAS 100-21 & 30 & $\mathrm{JNFb}$ & Acid & Yellow & Low \\
\hline UNIFENAS 100-26 & 42 & $\mathrm{JNFb}$ & Alkaline & Yellowish & Low \\
\hline UNIFENAS 100-39 & 30 & JNFb & Acid & Yellow & Medium \\
\hline UNIFENAS $100-40$ & 42 & JNFb & Acid/alckaline & Yellow & Low \\
\hline UNIFENAS 100-79 & 30 & LGI & Acid/alcaline & Yellow & High \\
\hline UNIFENAS 100-94 & 42 & $J M V$ & Acid & Yellow & Low \\
\hline \multicolumn{6}{|c|}{ Isolated in the municipality of Machado, MG } \\
\hline UNIFENAS 100-13 & 128 & $\mathrm{JNFb}$ & Acid & Yellow & High \\
\hline UNIFENAS 100-27 & 120 & LGI & Acid & Yellow & Medium \\
\hline UNIFENAS 100-85 & 120 & LGI & Acid /alcaline & Yellowish & High \\
\hline UNIFENAS 100-93 & 68 & JMV & Acid/alkaline & Yellowish & High \\
\hline
\end{tabular}

days, time enough to reach the log phase of growth, with approximately $109 \mathrm{ml}^{-1}$ of cells. Subsequently, $500 \mu \mathrm{L}$ of the bacterial suspensions were transferred to $50 \mathrm{~mL}$ of modified Aleksandrov liquid medium (Parmar \& Sindhu, 2013), with the following composition ( $\left.\mathrm{g} \mathrm{L}^{-1}\right)$ : Glucose 10.0; $\mathrm{MgSO}_{4} \cdot 7 \mathrm{H}_{2} \mathrm{O} 0.5 ; \mathrm{CaCO}_{3} 0.1 ; \mathrm{FeCl}_{3} 0.006 ; \mathrm{Ca}_{3} \mathrm{PO}_{4}$ 2.0; $\mathrm{pH}$ adjusted to 7.0 and $10 \mathrm{~g}$ of the phonolite rock as a potassium source containing $8.0 \%$ of $\mathrm{K}_{2} \mathrm{O}$, ground and sieved through a $0.25 \mathrm{~mm}(60$ mesh) mesh sieve. In addition to glucose as a carbon source, sucrose $\left(10.0 \mathrm{~g} \mathrm{~L}^{-1}\right)$ was also tested to verify the effect of the carbon source on the $\mathrm{K}$ solubilization potential of phonolite rock.

In addition to the treatments inoculated with the bacterial strains, a control treatment was also used, whose medium had the same composition (modified Aleksandrov medium containing $10 \mathrm{~g}$ of phonolite rock), without inoculation with bacterial strain.

The experiment was installed in a completely randomized design, in a $13 \times 2$ factorial scheme, with 12 bacterial strains and one control without inoculation and two carbon sources (sucrose and glucose) with four repetitions. The media were incubated at $25^{\circ} \mathrm{C}$ for seven days under agitation $\left(120 \mathrm{rpm}\right.$ at $\left.28^{\circ} \mathrm{C}\right)$ and after that time, the supernatant was separated by centrifugation $\left(10,000 \mathrm{rpm}\right.$ at $4^{\circ} \mathrm{C}$ and $\left.20 \mathrm{~min}\right)$ and the $\mathrm{pH}$ value was evaluated using a $\mathrm{pHmeter}$ and the soluble $\mathrm{K}$ concentration was evaluated with the aid of a flame photometer (Lopes-Assad et al., 2006).

The data were submitted to variance analysis and the means of the four replications were compared by the Scott-Knott's test at 5\% of probability, using the Sisvar software (Ferreira, $2011)$. The linear correlation analysis between $K$ concentrations and $\mathrm{pH}$ values for each carbon source was also performed using the AgroEstat software - version 1.0 (Barbosa \& Maldonado Júnior, 2011).

\section{Results and Discussion}

For the final $\mathrm{pH}$ values (Table 2), it is possible to observe that the inoculation with all the studied bacterial strains contributed to the final $\mathrm{pH}$ reduction of the medium when compared to control, except for the treatment with UNIFENAS 100-27 in the medium with sucrose, in which final $\mathrm{pH}$ value was similar to the value observed for the control treatment.

In the medium with glucose, treatments inoculated with the strains UNIFENAS 100-26, UNIFENAS 100-39, UNIFENAS 100-40, UNIFENAS 100-79 and UNIFENAS 100-94 presented final $\mathrm{pH}$ values about three units below the control treatment. In this same carbon source, among the treatments inoculated with the bacterial strains, it was observed that the inoculation with the strain 
UNIFENAS 100-85 resulted in the highest final $\mathrm{pH}$ value. For the culture medium containing sucrose as carbon source, the strain that promoted the greatest reduction in the $\mathrm{pH}$ of the medium was
UNIFENAS 100-40 and the one that had the least influence on the $\mathrm{pH}$ reduction was the UNIFENAS 100-27 strain.

Table 2. Values for final $\mathrm{pH}$ in the Aleksandrov culture medium supplemented with phonolite with two carbon sources, incubated for seven days ${ }^{(1)}$.

\begin{tabular}{ccc}
\hline & \multicolumn{2}{c}{ Final $\mathrm{pH}$} \\
\cline { 2 - 3 } Treatments & \multicolumn{2}{c}{ Carbon Source } \\
\cline { 2 - 3 } & Glucose & Sucrose \\
\hline Control & $6.84 \mathrm{~A} \mathrm{a}$ & $6.84 \mathrm{~A} \mathrm{a}$ \\
UNIFENAS 100-01 & $4.97 \mathrm{C} \mathrm{a}$ & $4.88 \mathrm{C} \mathrm{a}$ \\
UNIFENAS 100-13 & $4.16 \mathrm{D} \mathrm{b}$ & $4.76 \mathrm{C} \mathrm{a}$ \\
UNIFENAS 100-16 & $4.36 \mathrm{D} \mathrm{a}$ & $4.41 \mathrm{D} \mathrm{a}$ \\
UNIFENAS 100-21 & $4.14 \mathrm{D} \mathrm{a}$ & $4.40 \mathrm{D} \mathrm{a}$ \\
UNIFENAS 100-26 & $3.54 \mathrm{E} \mathrm{b}$ & $4.82 \mathrm{C} \mathrm{a}$ \\
UNIFENAS 100-27 & $4.19 \mathrm{D} \mathrm{b}$ & $6.74 \mathrm{~A} \mathrm{a}$ \\
UNIFENAS 100-39 & $3.86 \mathrm{E} \mathrm{b}$ & $4.30 \mathrm{D} \mathrm{a}$ \\
UNIFENAS 100-40 & $3.99 \mathrm{E} \mathrm{a}$ & $3.87 \mathrm{E} \mathrm{a}$ \\
UNIFENAS 100-79 & $3.89 \mathrm{E} \mathrm{b}$ & $4.41 \mathrm{D} \mathrm{a}$ \\
UNIFENAS 100-85 & $5.44 \mathrm{~B} \mathrm{a}$ & $5.72 \mathrm{~B} \mathrm{a}$ \\
UNIFENAS 100-93 & $4.73 \mathrm{C} \mathrm{b}$ & $5.76 \mathrm{~B}$ a \\
UNIFENAS 100-94 & $3.90 \mathrm{E} \mathrm{b}$ & $4.59 \mathrm{C} \mathrm{a}$ \\
\hline \multicolumn{2}{c}{ Means } & 4.46 \\
\hline M.Means followed by different letters, uppercase in column and lowercase in the line are different according to Scott Knott's test at 5\% of \\
probability.
\end{tabular}

The final $\mathrm{pH}$ of the medium containing glucose and inoculated with the strains UNIFENAS 100-13, UNIFENAS 100-26, UNIFENAS 100-27, UNIFENAS 100-39, UNIFENAS 100-79, UNIFENAS 10093 and UNIFENAS 100-94 strains was lower than the Final $\mathrm{pH}$ values of the medium containing sucrose and inoculated with the same strains.

The reduction of the medium $\mathrm{pH}$ promoted by the inoculation with the bacterial strains may be due to the production of different organic acids by the microbial metabolism (Sheng et al., 2008). The carbon source presented in the culture medium can interfere in the type of organic acid produced (Barroso et al., 2006).

All bacterial strains used in the study effectively contributed to the increase of soluble $\mathrm{K}$ contents in the culture medium when compared to the control treatment (Table 3). In the presence of glucose, the treatments with the highest levels of $\mathrm{K}$ were those inoculated with the strains UNIFENAS 100-13 and UNIFENAS 100-94. In the same medium, the treatments with the lowest $K$ contents were those inoculated with the strains UNIFENAS 100-27, UNIFENAS 100-85 and UNIFENAS 100-93. For the medium containing sucrose, the highest $\mathrm{K}$ content was observed in the treatments inoculated with the strains UNIFENAS 100-01,
UNIFENAS 100-21 and UNIFENAS 100-94 and the lowest $K$ value was observed in the treatment inoculated with UNIFENAS 100-27 strain.

The highest solubilization of $K$ of the phonolite rock by the strains UNIFENAS 10013 and UNIFENAS 100-94, when cultivated in medium containing glucose and UNIFENAS 10001, UNIFENAS 100-21 and UNIFENAS 100-94, in the presence of sucrose, showed no relation with the $K$ concentration in these soils of origin (Table 1).

By analyzing the $\mathrm{K}$ concentrations in the culture medium after bacterial growth and the final $\mathrm{pH}$ values, it is possible to relate these two parameters (Figure 1). In the medium containing glucose, this fact can be observed for the strain UNIFENAS 100-94, which presented high capacity in solubilizing $\mathrm{K}$ and promoted greater reduction in the $\mathrm{pH}$ of the culture medium. In the same medium, the opposite situation can be observed for the treatment inoculated with the strain UNIFENAS 100-85, presenting low capacity of $K$ solubilization and lower reduction of the medium $\mathrm{pH}$. When sucrose was used as a carbon source it was also possible to observe the same type of relationship between available $\mathrm{K}$ and $\mathrm{pH}$ of the medium for the treatment inoculated with the strain UNIFENAS 100-27 (Tables 2 and 3). Accordin 


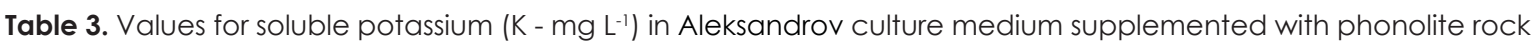
powder and two different carbon sources, incubated for seven days (1).

\begin{tabular}{ccc}
\hline & \multicolumn{2}{c}{$K\left(\mathrm{mg} \mathrm{L}^{-1}\right)$} \\
\cline { 2 - 3 } Treatments & \multicolumn{2}{c}{ Carbon Source } \\
\cline { 2 - 3 } Control & $11.00 \mathrm{D} \mathrm{a}$ & Sucrose \\
\cline { 2 - 4 } UNIFENAS 100-01 & $106.25 \mathrm{~B} \mathrm{a}$ & $11.25 \mathrm{E} \mathrm{a}$ \\
UNIFENAS 100-13 & $138.50 \mathrm{~A} \mathrm{a}$ & $115.50 \mathrm{~A} \mathrm{a}$ \\
UNIFENAS 100-16 & $96.00 \mathrm{~B} \mathrm{a}$ & $97.50 \mathrm{~B} \mathrm{~b}$ \\
UNIFENAS 100-21 & $117.50 \mathrm{~B} \mathrm{a}$ & $101.25 \mathrm{~B} \mathrm{a}$ \\
UNIFENAS 100-26 & $112.50 \mathrm{~B} \mathrm{a}$ & $120.75 \mathrm{~A} \mathrm{a}$ \\
UNIFENAS 100-27 & $55.75 \mathrm{C} \mathrm{a}$ & $103.25 \mathrm{~B} \mathrm{a}$ \\
UNIFENAS 100-39 & $115.25 \mathrm{~B} \mathrm{a}$ & $58.50 \mathrm{D} \mathrm{a}$ \\
UNIFENAS 100-40 & $106.75 \mathrm{~B} \mathrm{a}$ & $103.25 \mathrm{~B} \mathrm{a}$ \\
UNIFENAS 100-79 & $114.75 \mathrm{~B} \mathrm{a}$ & $109.25 \mathrm{~B} \mathrm{a}$ \\
UNIFENAS 100-85 & $43.75 \mathrm{C} \mathrm{b}$ & $76.75 \mathrm{C} \mathrm{b}$ \\
UNIFENAS 100-93 & $54.25 \mathrm{C} \mathrm{b}$ & $74.50 \mathrm{C} \mathrm{a}$ \\
UNIFENAS 100-94 & $132.75 \mathrm{~A} \mathrm{a}$ & $73.25 \mathrm{C} \mathrm{a}$ \\
\hline Means & 92.69 & $130.25 \mathrm{~A} \mathrm{a}$ \\
\hline (IMMeans followed by different letters, uppercase in column and lowercase in the line are different according to Scott Knott's test at 5\% of \\
probability.
\end{tabular}

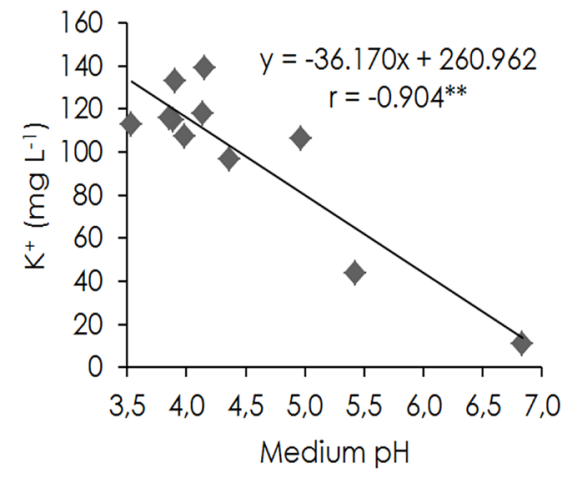

(A)

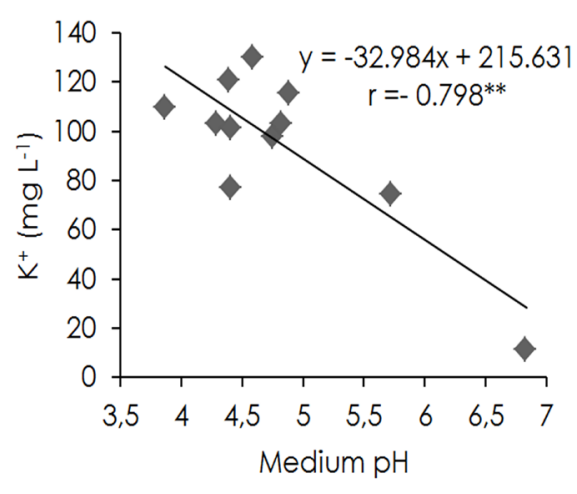

(B)

Figure 1. $\mathrm{K}$ concentration ( $\mathrm{mg} \mathrm{L}^{-1}$ ) and $\mathrm{pH}$ values for the Aleksandrov culture medium supplemented with phonolite rock and glucose (A) and sucrose (B) as carbon source, cultivated with different bacterial strains $* *=p<0.01$.

to Barroso et al. (2006), these results may be due to the properties of the metabolism of each bacteria strain, as well as the influence of the carbon source.

The relationship between $\mathrm{pH}$ reduction and increased $\mathrm{K}$ availability were observed by other authors (Lopes-Assad et al., 2006; Girgis et al., 2008), suggesting that the $\mathrm{pH}$ decrease, usually associated with the production of different organic acids, may be one of the mechanisms used by these bacteria to solubilize the mineral and release the $K$ present in their crystalline structure.

The production of organic acids has been pointed out as the main mechanism of $K$ solubiliziation by microorganisms (Hassan et al., 2010; Meena et al., 2014), and some strains analyzed in this experiment will be studied later in relation to the production and identification of organic acids.

The amount of $K$ released from the phonolite was dependent on the source of carbon used in the culture medium (Table 3). The strain UNIFENAS 100-13 presented higher solubilization of $\mathrm{K}$ in the presence of glucose, while the strains UNIFENAS 100-01 and UNIFENAS 100-21 showed higher concentrations of $K$ when sucrose was used as the carbon source.

Among the studied strains, it is possible to highlight UNIFENAS 100-94, which presented a high capacity to solubilize $K$ of phonolite rock powder when grown in both studied carbon sources, indicating greater metabolic versatility, having a good potential to solubilize $K$ in the soil. 
The strains that stood out in solubilizing $K$ should be included in new researches to identify the potential of solubilization of silicate minerals in the soil and, later, to evaluate the amount of $K$ that can be available to the plant.

\section{Conclusions}

The strains of UNIFENAS 100-01 and UNIFENAS 100-21 diazotophic bacteria presented greater potential in solubilizing $\mathrm{K}$ from phonolite rock powder in the presence of sucrose as a carbon source. Better results were observed for the strain UNIFENAS 100-13 in the presence of glucose and the strain UNIFENAS 100-94 for the high capacity to solubilize $K$ in the presence of the two studied carbon sources.

\section{Akcnowledgments}

To Capes for the Master's scholarship, Fapemig and $\mathrm{CNPq}$ for the scientific initiation scholarships and Fapemig for the financial support (Process: APQ-01115-14).

\section{References}

Alves, L., Oliveira, V.L., Filho, G.N.S. 2010. Utilization of rocks and ectomycorrhizal fungi to promote growth of eucalypt. Brazilian Journal Microbiology 41: 676-684.

ANDA. Associação Nacional para Difusão de Adubos e Corretivos Agrícolas. Anuário estatístico do setor de fertilizantes 2012. São Paulo: 2012. http://www.anda.org.br/multimidia/INDICE_DO_ ANUARIO_DE_2012.pdf/ <Access Jun $4^{\text {th }}, 2014>$.

Baldani, V.L.D., Baldani, J.I., Döbereiner, J. 2000. Inoculation of rice plants with the endophytic diazotrophs Herbaspirillum seropedicae and Burkholderia spp. Biology and Fertility of Soils, 30: 485-491.

Barbosa, J.C.; Maldonado Júnior, W. 2011. AgroEstat: sistema para análises estatísticas de ensaios agronômicos. Versão 1.0. Jaboticabal: FCAV/UNESP.

Barroso, C.B., Pereira, G.T., Nahas, E. 2006. Solubilization of $\mathrm{CAHPO}_{4}$ and $\mathrm{ALPO}_{4}$ by Aspergillus niger in culture media with different carbon and nitrogen sources. Brazilian Journal of Microbiology 37: 434-438.
Barroso, C.B., Nahas, E. 2008. Solubilização de fosfato de ferro em meio de cultura. Pesquisa Agropecuária Brasileira 43: 529-535.

Basak, B.B., Biswas, D.R. 2009. Influence of potassium solubilizing microorganism (Bacillus mucilaginosus) and waste mica on potassium uptake dynamics by sudangrass (Sorghum vulgare Pers.) grown under two Alfisols. Plant and Soil 317: 235-255.

Bonfim-Silva E.M., Monteiro F.A. 2006. Nitrogênio e enxofre em características produtivas do capimbraquiária proveniente de área de pastagem em degradação. Revista Brasileira de Zootecnia 35: 1289-1297.

DNPM. Departamento Nacional de Produção Mineral. Sumário Mineral. Brasil: 2014. 141 p. Available at: < http://www.dnpm.gov.br/dnpm/ paginas/sumario-mineral>

Döbereiner, J., Baldani, J.I., Baldani, V.L.D. 1995. Como isolar e identificar bactérias diazotróficas de plantas não leguminosas. Embrapa- CNPAB. Itaguaí, Brasil, 60p.

Ferreira, D.F. 201 1. SISVAR: A computer statistical analysis system. Ciência e Agrotecnologia 35: 1039-1042.

Girgis, M.G.Z., Khalii, H.M.A., Sharaf, M.S. 2008. In Vitro evaluation of rock phosphate and potassium solubilizing potential of some Bacillus strains. Australian Journal of Basic and Applied Sciences 2: 68-81.

Hassan, E.A., Hassan, E.A., Hamad, E.H. 2010. Microbial solubilization of phosphate-potassium rocks and their effect on khella (Ammi visnaga) growth. Annals of Agricultural Science 55: 37-53.

Leaungvutiviroj, C., Ruangphisarn, P., Hansanimitkul, P., Shinkawa, H., Sasaki, K. 2010. Development of a new biofertilizer with a high capacity for $\mathrm{N}_{2}$ fixation, phosphate and potassium solubilization and auxin production. Bioscience, Biotechnology, and Biochemistry 74: 1098-10101.

Lira-Cadete, L., Farias, A.R.B., Ramos, A.P.S., Costa, D.P., Freire, F.J., Kuklinsy-Sobral, J. 2012. Variabilidade genética de bactérias 
diazotróficas associadas a plantas de cana-deaçúcar capazes de solubilizar fosfato inorgânico. Bioscience Journal 28: 122-129.

Lopes-Assad, M.L., Rosa, M.M., Erler, G., CeccatoAntonini, S.R. 2006. Solubilização de pó-de-rocha por Aspergillus niger. Espaço \& Geografia 9: 1-17.

Mancuso, M.A.C. 2012. Fontes e doses de potássio na cultura do café (Coffea arabica L.). 61f. Dissertação (Mestrado) - Faculdade de Ciências Agronômicas - Universidade Estadual Paulista, Botucatu, Brasil.

Martins, E.S., Oliveira, C.G., Resende, A.V., Matos, M.S.F. 2008. Agrominerais - Rochas silicáticas como fontes minerais alternativas de potássio para a agricultura. In: Luz, A.B., Lins, F.F. (Ed). Rochas e Minerais Industriais: usos e especificações. 2. ed. Rio de Janeiro: CETEM/ MCTI, p.205-223.

Meena, V.S., Maurya, B.R., Verma, J.P. 2014. Does a rhizospheric microorganism enhance $\mathrm{K}^{+}$availability inagricultural soils? Microbiological Research, 169: 337-347.

Moreira, F.M.S., silva, K., Nóbrega, R.S.A., Carvalho, F. 2010. Bactérias diazotróficas associativas: diversidade, ecologia e potencial de aplicações. Comunicata Scientiae 1: 74-99.

Pádua, E.J. 2012. Rochagem como adubação complementar para culturas oleaginosas. 91f. (Master's thesis) - Universidade Federal de Lavras, Lavras, Brasil.

Parmar, P., Sindhu, S.S. 2013. Potassium Solubilization by Rhizosphere Bacteria: Influence of Nutritional and Environmental Conditions. Journal of M icrobiology Research 3: 25-31.

Phua, C.K.H., Abdul Wahid, A.N., Abdul Rahim K. 2012. Development of multifunctional biofer-tilizer formulation from indigenous microorganisms and evaluation of their $\mathrm{N}_{2}$-fixing capabilities on Chinese cabbage using ${ }^{15} \mathrm{~N}$ tracer technique. Tropical Agricultural Science 35: 673-9.

Sheng, X.F., Zhao, F., He, H., Qiu, G., Chen, L. 2008. Isolation, characterization of silicate mineral solubilizing Bacillus globisporus Q12 from the surface of weathered feldspar. Canadian
Journal of Microbiology 54: 1064-1068.

Souchie, E.L., Azcon, R., Barea, J.M., SagginJunior, O.J., Silva, E.M.R. 2005. Solubilização de fosfatos em meios sólido e líquido por bactérias e fungos do solo. Pesquisa Agropecuária Brasileira 40: $1149-1152$.

Teixeira, M.A.S., Garrido, F.M.S., Medeiros, M.E., Sampaio, J.A. 2012. Avaliação da rocha fonolito como fertilizante alternativo de potássio. Holos 5 : 21-33.

Wu, S.C., Cao, Z.H., Li, Z.G., Cheung, K.C., Wong, M.H. 2005. Effects of biofertilizer containing $\mathrm{N}$-fixer, $\mathrm{P}$ and $\mathrm{K}$ solubilizers and $\mathrm{AM}$ fungi on maize growth: a greenhouse trial. Geoderma 125: 155166. 